\title{
STRATEGI DINAS SOSIAL TENAGA KERJA DAN TRANSMIGRASI KABUPATEN SAMPANG DALAM MENGURANGI ANGKA PENGANGGURAN MELALUI METODE BALANCED SCORECARD
}

\author{
Rina Nur Azizah dan Rini Aristin \\ Program Studi Ilmu Administrasi Negara, FIA, Universitas Madura \\ Jl. Raya Panglegur KM. 3,5 Pamekasan \\ Email: rina_nurazizah@unira.ac.id
}

\begin{abstract}
High levels caused by factors that are not proportional to the level of education and the level of education of the community, which is the subject matter. This type of research is in the form of a case study using the balanced scorecard method. Data collection takes several elements and then each of these elements is examined, conclusions that only apply to the elements studied only. This research was conducted at the Sampang Regency Cooperative, Micro Business and Manpower Office. The results of the study averaged 0.5, which means the performance of the Micro, Cooperative and Cooperative Office of Sampang Regency. These results are the average results from several aspects, namely data that shows an internal NGR of $80 \%$ that is well-intentioned. The internal business perspective data produces a target of employee returns of 5\% which means less. Internal business perspective data on employee training results is $50 \%$ which means less. Data to measure employee training level by $50 \%$ which means less.
\end{abstract}

Keywords: Balanced Scorecard, Unemployment.

\begin{abstract}
Abstrak: Tingginya tingkat pengangguran disebabkan oleh beberapa faktor diantaranya besarnya angkatan kerja yang tidak seimbang dengan kesempatan kerja serta tingkat pendidikan dan keterampilan yang dimiliki masyarakat, inilah yang menjadi pokok permasalahan. Jenis penelitian yang digunakan berupa studi kasus dengan menggunakan metode balanced scorecard. Pengumpulan data mengambil beberapa elemen dan kemudian masing-masing elemen tersebut diteliti, kesimpulan yang ditarik hanya berlaku untuk elemen-elemen yang diteliti saja. Penelitian ini dilakukan di Dinas Koperasi, Usaha Mikro dan Tenaga Kerja Kabupaten Sampang. Hasil penelitian menunjukkan nilai rata-rata sebesar 0,5 yang berarti kinerja Dinas Koperasi Usaha Mikro dan Tenaga Kerja Kabupaten Sampang dikatakan Cukup. Hasil tersebut merupakan hasil rata-rata dari beberapa aspek, diantaranya data perspektif bisnis internal menunjukkan hasil NGR sebesar $80 \%$ yang berarti baik. Data perspektif bisnis internal menunjukkan hasil target kepuasan karyawan sebesar 5\% yang berarti kurang. Data perspektif bisnis internal menunjukkan hasil persentase pelatihan karyawan sebesar $50 \%$ yang berarti kurang. Data perspektif bisnis internal menunjukkan persentase pelatihan karyawan sebesar 50\% yang berarti kurang.
\end{abstract}

Kata Kunci: Balanced Scorecard, Pengangguran.

\section{PENDAHULUAN}

Saat ini pengangguran merupakan permasalahan yang sulit diatasi, baik dari tingkat pemerintah maupun dari masyarakatnya itu sendiri. Cara mengurangi angka pengangguran yang direncanakan oleh pemerintah sudah ditempuh namun masih belum terselesaikan juga. Pengangguran ini muncul karena terjadi ketidaksesuaian antara lapangan kerja dan pencari kerja. Sehingga hal tersebut pada akhirnya juga akan mengakibatkan terjadinya tindak kejahatan. 
REFORMASI

ISSN 2088-7469 (Paper) ISSN 2407-6864 (Online)

Volume 8 Nomor 2 (2018)

Salah satu daerah yang mendapat program dalam mengurangi angka pengangguran dengan metode balanced scorecard adalah Kabupaten Sampang melalui Bidang Ketenagakerjaan. Bidang ini sebelumnya bergabung dengan Dinas Sosial pada organisasi perangkat daerah (OPD) Dinas Sosial Tenaga Kerja dan Transmigrasi Kabupaten Sampang, akan tetapi pada bulan Januari 2018 Bidang Ketenagakerjaan ini berubah nama menjadi Bidang Pengembangan dan Penempatan Tenaga Kerja yang bergabung pada OPD Dinas Koperasi, Usaha Mikro dan Tenaga Kerja Kabupaten Sampang.

Hasil laporan evaluasi kinerja Dinas Koperasi, Usaha Mikro dan Tenaga Kerja walaupun secara umum telah berjalan dengan baik tetapi dalam pelaksanaannya masih mengalami beberapa kendala. Pada saat proses perencanaan, data-data yang dimiliki oleh Dinas koperasi, Usaha Mikro dan Tenaga Kerja sangat kurang. Data awal tentang kondisi masyarakat masih susah diperoleh sehingga dalam penetapan pencapaian target dalam kegiatan menjadi sulit diberikan secara jelas. Data dan informasi yang kurang ini menjadi penyebab pencapaian target menjadi kurang maksimal.

Dalam melaksanakan strategi yang telah ditetapkan oleh Dinas Koperasi, Usaha Mikro, dan Tenaga Kerja dalam mengurangi angka pengangguran, pengukuran kinerja beserta evaluasinya menjadi sangat penting. Kinerja dapat dijadikan sebagai tolak ukur dalam mengetahui keberhasilan strategi Dinas Koperasi, Usaha Mikro dan Tenaga Kerja Kabupaten Sampang tersebut, selain itu pengukuran kinerja juga memperlihatkan kontribusi para pegawai terhadap program kerja serta menjadi sumber informasi dalam mengevaluasi tindakan pegawai.

\section{A. Pengangguran}

Menurut Hartini dan G. Kartasapoetra (Hariadi, 2009: 22) pengangguran adalah suatu kenyataan apabila orang atau tenaga kerja tidak mendapatkan pekerjaan. Sedangkan menurut Suroto (1992: 29) pengangguran adalah orang yang mampu bekerja, tidak mempunyai pekerjaan dan ingin bekerja atau baik secara aktif, maupun pasif mencari pekerjaan. Manning dan Efendi (Syamsi, 2009:4), mengatakan jumlah pengangguran dan setengah pengangguran yang besar dan semakin meningkat, proporsi tenaga kerja yang bekerja pada sektor industri dikota hampir tidak dapat bertambah dan malahan mungkin semakin berkurang, jumlah penduduk dan dan tingkat pertumbuhannya sudah begitu pesat sehingga pemerintah tidak mampu memberikan pelayanan kesehatan, pertumbuhan, transportasi yang memadai.

\section{B. Balanced Scorecard}

Balanced Scorecard ini pertama kali diperkenalkan oleh Kaplan dan Norton pada tahun 1990an, sebagai alat ukur kinerja manajemen. Teknik Balanced Scorecard mengandung empat perspektif, yaitu perspektif keuangan, pelanggan, internal, serta pembelajaran dan pertumbuhan. Keempat perspektif menawakan suatu keseimbangan (Balance) antara tujuan jangka pendek dan tujuan jangka panjang, yaitu hasil (outcome) yang diinginkan pemicu, kinerja dan tolak ukur.

Balanced Scorecard mempertahankan perspektif keuangan karena tolak ukur keuangan berguna untuk mengikhtisarkan konsekuensi tindakan ekonomi yang telah diambil. Tujuan finansial biasanya berkaitan dengan pengukuran kemampulabaan. Perspektif keuangan menggambarkan konsekuensi tindakan ekonomi yang diambil dalam 


\section{REFORMASI}

ISSN 2088-7469 (Paper) ISSN 2407-6864 (Online)

Volume 8 Nomor 2 (2018)

ketiga perspektif yang lain. Perspektif pelanggan mendefinisikan pelanggan dan segmen pasar dimana unit usaha akan bersaing. Perspektif proses bisnis internal melukiskan proses internal yang diperlukan untuk memberikan nilai bagi pelanggan dan pemilik. Perspektif pembelajaran dan pertumbuhan mendefinisikan kapabilitas yang diperlukan induk organisasi untuk menciptakan pertumbuhan jangka panjang dan perbaikan.

Gambar di bawah ini menunjukkan alur yang dilalui dalam penelitian kinerja menurut pendekatan Balanced Scorecard.

\section{Gambar 1. alur penelitian kinerja menurut pendekatan Balanced Scorecard}

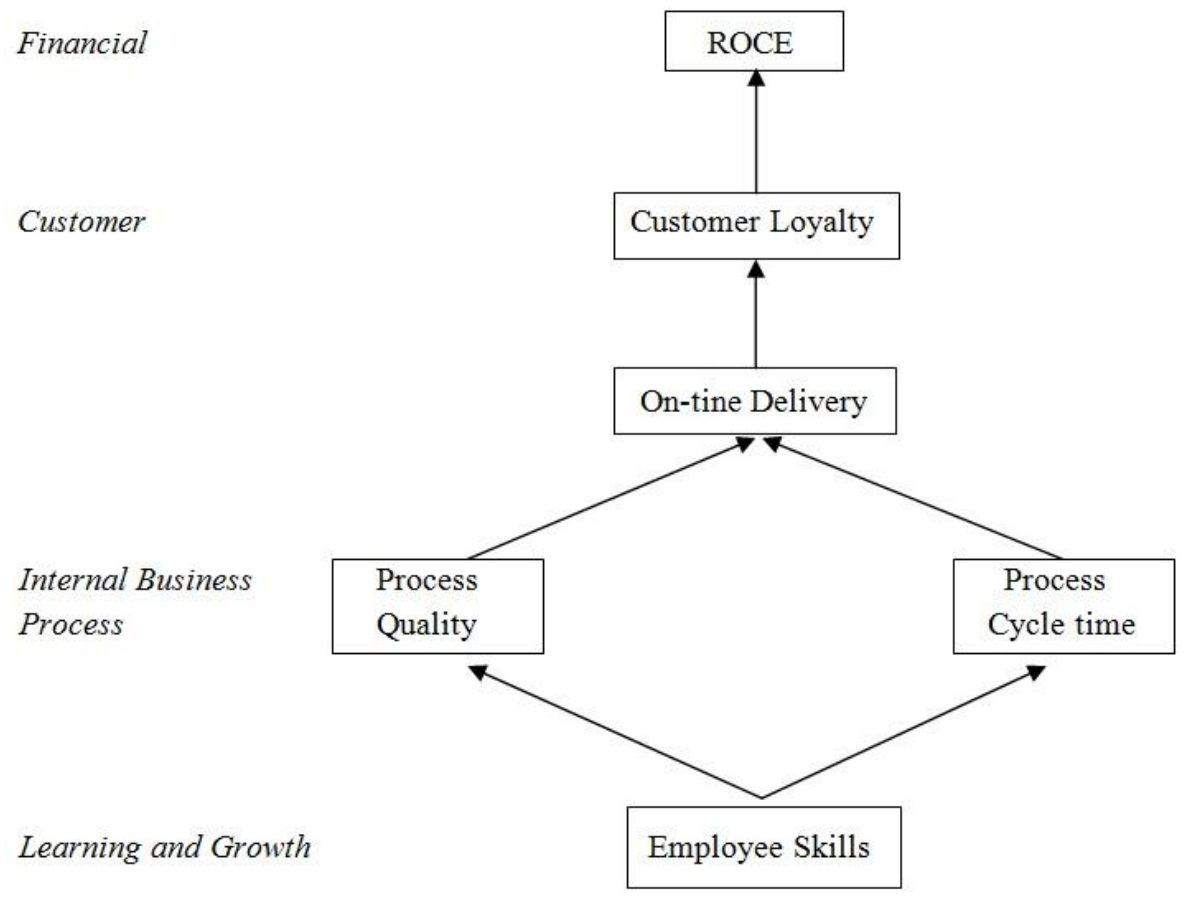

\section{Balanced Scorecard Untuk Perencanaan Strategik Sektor Publik}

Perencanaan strategik merupakan penerjemahan strategi ke dalam sasaran-sasaran strategik, ukuran kinerja, dan target kinerja serta penentuan inisiatif strategik untuk mewujudkan sasarn strategik (Mulyadi, 2001). Dengan menggunakan kerangkan Balanced Scorecard tahapan dalam proses perencanaan strategik terdiri atas empat langkah, yaitu :

1. Penerjemahan strategi ke dalam berbagai sasaran strategik dalam empat perspektif: pelanggan, keuangan, proses internal, serta pembelajaran dan pertumbuhan;

2. Penentuan ukuran kinerja, yaitu berupa indikator kinerja yang terdiri atas ukuran hasil (outcome meansure) dan ukuran pemacu kinerja (perfomance driver meansure);

3. Penentuan target kinerja, yaitu target kinerja yang hendak dicapai dalam rangka pencapaian sasaran strategik untuk jangka waktu tertentu;

4. Perumusan inisiatif strategik, yaitu langkah strategik yang dipilih untuk mewujudkan sasaran strategik.

\section{Balanced Scorecard Untuk Penyusunan Program}

Penyusunan program yang dilakukan setelah perencanaan strategik adalah sasaran strategik, target kinerja, dan inisiatif strategik dan harus dijabarkan dalam bentuk program- 


\section{REFORMASI}

ISSN 2088-7469 (Paper) ISSN 2407-6864 (Online)

Volume 8 Nomor 2 (2018)

program. Jika output perumusan strategi dan perencanaan strategik bersifat kualitatif, maka output tahap pemrograman harus kuantitatif, baik dalam hal keuangan maupun non keuangan.

Tahap penyusunan program dalam organisasi sektor publik, khususnya dalam pemerintahan, dibagi menjadi dua tingkatan. Tingkat pertama adalah program makro yang dituangkan dalam bentuk Rencana Pembangunan Jangka Menengah Nasional/Daerah (RPJM Nasional/Daerah). Tingkat kedua adalah program mikro, yaitu pada program masing-masing Kementerian/Lembaga/satuan Kerja Perangkat Daerah yang dituangkan dalam Rencana Strategis (Renstra) dan Rencana Kerja (Renja) Instansi. RPJM Nasional/Daerah merupakan operasionalisasi dari Rencana Pembangunan Jangka Panjang Nasional/Daerah (RPJP Nasional/Daerah) yang memuat visi, misi, arah dan kebijakan pembangunan.

Penggunaan Balanced Scorecard dalam penyusunan program digunakan untuk menjabarkan inisiatif strategik ke dalam program-program yang terbagi pada tiga perspektif. Program disusun untuk masing-masing perspektif pelanggan, proses internal, serta pembelajaran dan pertumbuhan. Dengan demikian, atara tahap perencanaan strategik dengan tahap pemrograman terjadi koherensi dan konsistensi.

\section{E. Balanced Scorecard dalam tahap Penganggaran}

Tahap selanjutnya dalam manajemen stategik setelah penyusunan program adalah penganggaran. Sebagaimana telah disebutkan di awal bahwa tahap pemrograman bersifat kuantitatif, baik kuantitatif keuangan maupun non keuangan. Dalam tahap pembuatan program, kebutuhan sumberdaya atau investasi yang diperlukan untuk melaksanakan masing-masing program sudah diperhitungkan.

Tahap pembuatan program terkait dengan perencanaan keuangan jangka panjang, yaitu lebih dari satu tahun. Sementara, penganggaran merupakan perencanaan keuangan jangka pendek, yaitu satu tahun. Hubungan antara tahap pemograman dengan penganggaran adalah program yang telah disetujui dalam tahap pemrograman akan digunakan sebagai dasar untuk menyusun anggaran tahunan.

\section{F. Konsep Dasar Balanced Scorecard}

Dengan mempertimbangkan manfaat yang akan diperoleh balanced scorecard yang dijadikan pilihan menjadi model pengukuran kinerja memiliki pandangan bahwa pengukuran kinerja organisasi akan menyangkut empat perspektif berikut:

1. Perspektif Keuangan

Dalam perspektif ini, kinerja keuangan tetap digunakan untuk mengukur apakah dalam strategi organisasi, implementasi strategi hingga pelaksanaan akan membawa dampak positif bagi organisasi. Setiap pengukuran pasti akan memiliki hubungan sebab akibat yang diharapkan nantinya akan dapat meningkatkan kinerja keuangan organisasi. Mempertahankan perspektif keuangan dalam balance scorecard karena ukuran keuangan sangat berperan penting dalam proses tumbuh kembang suatu organisasi hingga tindakan ekonomis yang diambil oleh organisasi. Pada perspektif ini, tujuan dan ukuran keuangan harus dapat berperan ganda sehingga pada akhirnya dapat menentukan strategi, sasaran akhir dari sebuah tujuan yang telah disusun.

2. Perspektif Pelanggan (Nonfinansial) 


\section{REFORMASI}

ISSN 2088-7469 (Paper) ISSN 2407-6864 (Online)

Volume 8 Nomor 2 (2018)

Perspektif pelanggan adalah salah satu indikator yang cukup menentukan organisasi meraih tujuan. Suatu organisasi memiliki suatu produk atau jasa yang dapat memberikan keuntungan / nilai lebih bagi konsumen / pelanggan apabila manfaat yang diterimanya relatif lebih tinggi dibandingkan pengorbanan yang dilakukan untuk mendapatkan produk/jasa tersebut.

3. Prespektif Proses Bisnis Internal

Proses bisnis internal merupakan suatu rangkaian kegiatan yang berjalan pada suatu bisnis internal dan seringkali juga disebut sebagai rantai nilai (Value Chain). Pada rantai nilai ini akan terdiri atas perencanaan, produksi, layanan purna jual, bahkan hingga jaminan keamanan dan kesehatan mulai dari produk tersebut dikembangkan hingga sampai ketangan konsumen.

4. Perspektif Pertumbuhan dan Pembelajaran

Perspektif ini akan menunjukkan bagaimana suatu organisasi dapat bertahan dan mampu berubah, tumbuh sesuai dengan tuntunan eksternal.

\section{G. Menyusun Strategi Dengan Balanced Scorecard}

Organisasi akan dapat melakukan aktivitasnya dengan baik bila memiliki visi, misi dan perencanaan yang matang. Perencanaan strategi yang dilakukan dengan melalui tahapan penilaian, evaluasi, dan pengambilan keputusan yang nantinya akan menghasilkan suatu pedoman kerja untuk jangka waktu 3 hingga 5 tahun ke depan bagi organisasi. Pedoman kerja inilah yang natinya akan menjadi dasar bagi organisasi untuk mengelola dan mengidentifikasi kekurangan dan kelebihan internal. Berikut ini langkah-langkah dalam penyusunan strategi :

1. Menentukan tujuan

Pemimpin atau manajer puncak melakukan pemilihan tujuan yang strategis. Biasanya pemilihan ini dipengaruhi oleh tujuan-tujuan yang dianut manajer, disamping kekuatan dan kelemahan organisasi. Tujuan-tujuan dilaksanakan tersebut harus sesuai dengan visi dan misi organisasi.

2. Melakukan analisis lingkungan

Tujuan yang menjadi pilihan organisasi yang akan menggunakan metode SWOT (Strenght and Weakness untuk lingkungan internal/mikro dan Opportunity and Threats untuk lingkungan eksternal/makro). Pada umumnya melakukan analisis lingkungan dilakukan dengan dua cara berikut:

a. Melakukan analisis terhadap kecenderungan faktor dan masalah utama potensial yang cenderung harus dihadapi pada masa yang akan datang.

b. Mengetahui analisis untuk mengetahui hubungan antara strategi organisasi dan tanggapan yang berasal dari lingkungan. Data analisis inilah yang dapat dijadikan sebagai dasar untuk melakukan perbadingan antara strategi yang saat ini digunakan dan strategi yang akan digunakan dimasa mendatang.

3. Menetapkan ukuran

Dengan menetapkan ukuran, organisasi akan dapat melakukan hal-hal sebagai berikut:

a. Membantu manajemen di tingkat bawah untuk ikut menyusun rencana.

b. Menjadi tolok ukur keberhasilan dan kegagalan proses.

c. Mempermudah dalam mencapai tujuan yang ditetapkan sebelumnya dengan cara yang efektif dan efisien. 


\section{REFORMASI}

ISSN 2088-7469 (Paper) ISSN 2407-6864 (Online)

Volume 8 Nomor 2 (2018)

4. Membuat rencana unit

Manajer bagian umum tentatif ikut serta dalam merumuskan tujuan jangka panjang. Oleh karena itu, organisasi juga akan melibatkan manajer bawah untuk berperan serta dalam membantu tercapainya tujuan jangka panjang tersebut.

5. Melakukan perbandingan antara rencana unit dan rencana strategis

Ada kalanya terjadi perbedaan yang cukup mencolok antara rencana yang dibuat oleh unit-unit dan rencana strategi organisasi. Untuk itu, organisasi dalam hal ini manajer tingkat atas, hendaknya mensosialisasikan rencana strategis organisasi kepada unit-unit kerja dengan lebih komunikatif sehingga bisa meminimalkan perbedaan dengan cara menyesuaikan satu sama lain antara unit kerja dan rencana strategis yang disusun oleh organisasi dalam hal ini oleh perencanaan strategis.

6. Melakukan pemilihan dari beberapa alternatif untuk mencapai tujuan

Manajer bersama-sama dengan manajer dibawahnya dan karyawan, bersama-sama melakukan inventarisasi alternatif untuk mencapai tujuan organisasi.

7. Mengimplementasikan rencana

Rencana dan strategis yang telah disusun akan dirumuskan menjadi kegiatan operasional yang berlaku bagi seluruh elemen dalam organisasi.

8. Monitoring, mengukur, mengevaluasi dan mengawasi kemajuan

Melaksanakan kegiatan operasional dalam suatu organisasi tentunya tidak akan lepas dari banyaknya masukan baru yang akan menyesuaikan dengan kondisi saat proses pelaksanaan rencana berlangsung, agar operasional tidak melenceng jauh dari rencana strategis. Untuk itu, dibutuhkan:

a. Penyusunan standar yang digunakan sebagai tolok ukur untuk mengetahui kemajuan.

b. Melakukan umpan balik antara perencanaan strategi dan pelaksana untuk mengetahui hasil-hasil operasional.

c. Melakukan koreksi jika terjadi penyimpangan / tidak sesuai standar yang telah ditetapkan sebelumnya oleh perencana strategi dalam hal ini manajer tingkat atas.

d. Pembuatan matriks pelaksanaan program yang disusun sejak proses perencanaan dimulai dari perencanaan hingga evaluasi program dapat dipertanggungjawabkan sehingga dapat digunakan sebagai dasar penilaian kinerja.

\section{METODE PENELITIAN}

Metode yang digunakan dalam penelitian ini adalah berupa studi kasus, yaitu metode pengumpulan data dengan mengambil beberapa elemen untuk diteliti, kesimpulan yang ditarik hanya berlaku untuk elemen-elemen yang diteliti. Penelitian ini dilakukan pada Dinas Koperasi Usaha Mikro dan Tenaga Kerja Kabupaten Sampang dengan data berupa elemen-elemen yang menjadi tolak ukur dalam pengukuran kinerja, dengan metode Balanced Scorecard.

Penggunaan pengukuran kinerja dengan metode Balanced Scorecard dilakukan dengan empat perspektif utama, yaitu Financial Perspective (Perspektif Keuangan), Customer Perspective (Perspektif Pelanggan), Internal Bisnis Perspective (Perspektif proses bisnis internal), Learning and Growth Perspective (Pembelajaran dan Pertumbuhan). Teknik pengumpulan data menggunakan kuesioner dan dokumentasi. 
REFORMASI

ISSN 2088-7469 (Paper) ISSN 2407-6864 (Online)

Volume 8 Nomor 2 (2018)

\section{PEMBAHASAN}

\section{A. Perbandingan Hasil Penelitian Dengan Teori}

1. Financial Perspective (Perspektif Keuangan)

a. Penggunaan anggaran yang efektif

Tingkat pencapaia tolak ukur kinerja di setiap kegiatan program yang telah ditargetkan oleh Dinas Koperasi, Usaha Mikro dan Tenaga Kerja Kabupaten Sampang dalam mengurangi angka pengangguran.

b. Penggunaan anggaran yang efisien

Realisasi anggaran yang diusulkan pada APBD TK I maupun tingkat daerah dan pusat sesuai dengan target yang telah ditentukan oleh Dinas Koperasi, Usaha Mikro dan Tenaga Kerja Kabupaten Sampang dalam mengurangi angka pengangguran

2. Customer Perspective (Perspektif Pelanggan)

a. Kepuasan Stakeholder, dalam melaksanakan program kegiatan dalam mengurangi angka pengangguran, Dinas Koperasi, Usaha Mikro dan Tenaga Kerja Kabupaten Sampang bekerjasama dengan berbagai pihak. Antara lain adalah UPT. BLK Kabupaten Sumenep, UPT. Dinas Koperasi tingkat provinsi dan Balai Besar.

b. Kepuasan Masyarakat, meningkatkan program kegiatan dalam mengurangi angka pengangguran di Kabupaten Sampang, misalnya dengan mengadakan kewirausahaan dan pelatihan dengan tepat sasaran. Artinya tepat sasaran disini adalah masyarakat yang benar-benar membutuhkan kegiatan program tersebut.

c. Peningkatan pemerataan wirausaha, dalam menyelenggarakan program kegiatan pelatihan kewirausahaan di wilayah sasaran yang memiliki potensi yang perlu dikembangkan maka memiliki dampak positif dalam mengurangi angka pengangguran.

d. Peningkatan mutu kewirausahaan, dalam melaksanakan kegiatan program pada tahap akhir biasanya diadakan evaluasi yang bertujuan untuk melihat berhasil atau tidaknya kegiatan program yang diselenggarakan oleh Dinas Koperasi Usaha Mikro dan Tenaga Kerja Kabupaten Sampang. Dapat dikatakan berhasil bila adanya tindak lanjut setelah program selesai, yaitu terciptanya wirausaha baru dalam pengembangan kwirausahaan.

3. Internal Bisnis Perspective (Perspektif proses bisnis internal)

a. Peningkatan Pemahaman Memberikan Pelayanan, meningkatkan pemahaman dalam memberikan pelayanan terhadap kegiatan program pelatihan sehingga mampu menciptakan lapangan pekerjaan sendiri dengan memiliki skill yang diperolehnya.

b. Pengelolaan Organisasi, program kegiatan dalam mengurangi pengangguran di Kabupaten Sampang harus diperhatikan bagaimana cara mengelola kelompok pelatihan yang sudah dibentuk pada tahapan awal kegiatan. Setelah terbentuknya kelompok pelatihan maka dilakukan pemberdayaan dan pengarahan sehingga memiliki tindak lanjut program program yang sudah terlaksana.

c. Pemanfaatan teknologi, informasi dan komunikasi

Dinas Koperasi Usaha Mikro dan Tenaga Kerja Kabupaten Sampang selalu memanfaatkan teknologi dn Informasi ter-update dalam pelaksanaan kegiatan program dalam mengurangi angka pengangguran di Kabupaten Sampang. Jaringan komunikasinya pun juga sangat luas, antara lain memiliki kerja sama dengan UPT. BLK Kabupaten Sumenep dalam pelaksanaan kegiatan program tersebut. 


\section{REFORMASI}

ISSN 2088-7469 (Paper) ISSN 2407-6864 (Online)

Volume 8 Nomor 2 (2018)

d. Pengadaan perlengkapan kegiatan pelatihan dalam pengembangan kewirausahaan Berdasarkan kegiatan program pelatihan yang dilaksanakan oleh Dinas Koperasi Usaha Mikro dan Tenaga Kerja Kabupaten Sampang semua perlengkapannya sudah tersedia. Misalkan pada pelatihan menjahit sudah tersedia mesin jahit, demikian juga pada pelatihan tata boga, perlengkapan masak memasak juga sudah disediakan. Bahkan peserta pelatihan dibekali segala perlengkapan sesuai program pelatihannya guna mengembangkan kemampuannya setelah mengikuti pelatihan.

4. Learning and growth perspective (pembelajaran dan pertumbuhan) dengan cara meningkatkan mutu SDM

a. Mengembangkan pelatihan dalam kewirausahaan

Dalam memberdayakan masyarakat, Dinas Koperasi Usaha Mikro dan Tenaga Kerja Kabupaten Sampang berupaya untuk mengadakan kegiatan pelatihan dalam mengembangan kewirausahaan. Pelatihan-pelatihan tersebut antara lain adalah pelatihan bengkel atau montir, pelatihan komputer, pembuatan tahu tempe, pembuatan kue, pengolahan hasil ikan serta pelatihan menjahit.

b. Mengembangkan wirausaha yang produktif

Setelah dilakukan program pelatihan, dan para pengangguran memperoleh bekal, maka Dinas Koperasi, Usaha Mikro dan Tenaga Kerja Kabupaten Sampang berharap supaya para pengangguran mampu mengembangkan ketrampilan yang diperolehnya sehingga mampu menciptakan wirausaha baru. Dengan menciptakan wirausaha yang produktif maka akan teratasi masalah perekonomian yang dihadapinya.

c. Merubah masyarakat non produktif dalam pengembangan jiwa kewirausahaan yang diperolehnya

Setelah diadakannya program pelatihan, harapan Dinas Koperasi, Usaha Mikro dan Tenaga Kerja Kabupaten Sampang mampu merubah masyarakat yang pengangguran dengan mengembangkan jiwa kewirausahaan yang diperoleh maka mampu mengatasi masalah ekonominya, selain masalah ekonomi masyarakat pengangguran juga mampu mengatasi masalah sosialnya.

\section{B. Kinerja Pegawai Secara Keseluruhan}

Metode Pengukuran Perspektif Kueangan dan Non Keuangan Kinerja Pegawai Secara Keseluruhan dapat dilihat pada tabel berikut:

Tabel 1. Metode Pengurukan Perspektif Kueangan dan Non Keuangan

\begin{tabular}{|c|l|l|l|}
\hline No & \multicolumn{1}{|c|}{ Variabel } & \multicolumn{1}{|c|}{ Dimensi } & \multicolumn{1}{|c|}{ Keterangan } \\
\hline 1. & $\begin{array}{l}\text { Perspektif } \\
\text { Keuangan }\end{array}$ & $\begin{array}{l}\text { Perspektif keuangan yang } \\
\text { menggambarkan prestasi } \\
\text { perusahaan yang diukur dari } \\
\text { sisi keuangan }\end{array}$ & $\begin{array}{l}\text { ROE } \\
\text { ROA } \\
\text { Operating Income } \\
\text { Eficiency Cost } \\
\text { Total Asset Turnover }\end{array}$ \\
\hline 2. & $\begin{array}{l}\text { Perspektif } \\
\text { Pelanggan }\end{array}$ & $\begin{array}{l}\text { Perspektif pelanggan yang } \\
\text { menggambarkan tingkat } \\
\text { kepuasan pelanggan terhadap } \\
\text { produk, harga distribusi dan } \\
\text { pelayanan }\end{array}$ & $\begin{array}{l}\text { Data Kuesioner } \\
\text { Pelanggan }\end{array}$ \\
\hline 3. & Perspektif $\quad$ Bisnis & Perspektif proses bisnis & Operating Profit \\
\hline
\end{tabular}




\section{REFORMASI}

ISSN 2088-7469 (Paper) ISSN 2407-6864 (Online)

Volume 8 Nomor 2 (2018)

\begin{tabular}{|c|l|l|l|}
\hline & Internal & $\begin{array}{l}\text { internal menggambarkan } \\
\text { proses internal yang } \\
\text { memberikan nilai bagi } \\
\text { pelanggan dan pemilik }\end{array}$ & \\
\hline 4. & $\begin{array}{l}\text { Perspektif } \\
\text { Pembelajaran dan } \\
\text { Pertumbuhan }\end{array}$ & $\begin{array}{l}\text { Perspektif pembelajaran dan } \\
\text { pertumbuhan menggambarkan } \\
\text { kemampuan individu } \\
\text { perusahaan dalam } \\
\text { meningkatkan laba dan nilai } \\
\text { perusahaan }\end{array}$ & $\begin{array}{l}\text { Net Income per } \\
\text { Emee }\end{array}$ \\
\hline
\end{tabular}

1. Financial Perspective (Perspektif Keuangan)

Keuangan Dinas Koperasi, Usaha Mikro Dan Tenaga Kerja

Kabupaten Sampang

\begin{tabular}{|c|c|c|c|c|l|c|}
\hline $\begin{array}{c}\text { Perspektif } \\
\text { Keuangan }\end{array}$ & $\mathbf{2 0 1 8}$ & $\mathbf{2 0 1 7}$ & $\mathbf{2 0 1 6}$ & $\begin{array}{c}\text { Rata- } \\
\text { Rata }\end{array}$ & Kriteria & Skor \\
\hline ROE & $12 \%$ & $9,3 \%$ & $8,7 \%$ & $10 \%$ & Cukup & 0 \\
\hline ROA & $7,4 \%$ & $4,3 \%$ & $3,2 \%$ & $4,96 \%$ & Kurang & -1 \\
\hline Operating Income & $12,41 \%$ & $10,43 \%$ & $11,81 \%$ & $11,55 \%$ & Cukup & 0 \\
\hline Efficiency Cost & $53,27 \%$ & $53,27 \%$ & $53,36 \%$ & $53,30 \%$ & Baik & 1 \\
\hline $\begin{array}{c}\text { Total Asset Turn } \\
\text { Over }\end{array}$ & $85,08 \%$ & $77,3 \%$ & $77,07 \%$ & $79,81 \%$ & Baik & 1 \\
\hline
\end{tabular}

Sumber : Data Primer Yang Diolah (2016-2018)

\section{Keterangan :}

1. ROE (Return on Equelity) $=\mathrm{EAT} /$ Total Equity

2. ROA (Return on Assets) $=$ EAT / Total Aktiva

3. Operating Income $=$ Pendapatan Bersih - Biaya Usaha

4. Efficiency Cost = Beban Biaya / Pendapatan Bersih

5. Total Asset Turn Over $=$ Penjualan Netto $/$ Total Aktiva

Hasil penilaian kinerja dilihat dari perspektif keuangan adalah menunjukkan bahwa ROE mempunyai rata-rata cukup, sehingga diberi skor 0 . Karena rata-rata ROE sudah hampir mendekati standar yang telah ditetapkan. Sedangkan pada ROA menunjukkan ratarata kurang, sehingga diberi skro -1. Karena nilai ROA masih jauh dibawah standar yang ada. Untuk Operating Income diberi skor karena mempunyai rata-rata cukup. Dan untuk Efficiency Cost diberi skor 1 karena nilai sudah baik.

\section{Customer Perspective (Perspektif Pelanggan)}

Pengukuran kinerja pada perspektif ini adalah tingkat kepuasan pelanggan (Customer Satisfaction), dengan cara mengukur seberapa besar kepuasan pelanggan terhadap pelayanan perusahaan. Data diperoleh dari penyebaran kuesioner kepada pelanggan. 
Tabel 2. Data Hasil Kuesioner

\begin{tabular}{|c|c|c|c|}
\hline No. & Kuesioner & Keterangan & Skor \\
\hline 1. & Kuesioner 1 & Baik & 1 \\
\hline 2. & Kuesioner 2 & Baik & 1 \\
\hline 3. & Kuesioner 3 & Baik & 1 \\
\hline 4. & Kuesioner 4 & Cukup & 0 \\
\hline 5. & Kuesioner 5 & Baik & 1 \\
\hline 6. & Kuesioner 6 & Cukup & 0 \\
\hline 7. & Kuesioner 7 & Baik & 1 \\
\hline 8. & Kuesioner 8 & Kurang & -1 \\
\hline 9. & Kuesioner 9 & Baik & 1 \\
\hline 10. & Kuesioner 10 & Cukup & 0 \\
\hline Total Rata-Rata & & $\mathbf{0 , 5}$ \\
\hline
\end{tabular}

Sumber Data : Data Primer yang diolah (Dalam angka 2018)

Dalam menentukan kriteria kinerja "kurang", "cukup", dan "baik" dengan membuat skala penilaian kinerja balanced scorecard dari hasil pemberian skor pada masing-masing hasil kuesioner yang diperoleh. Kinerja dikatakan "kurang" jika besar nilainya kurang dari $50 \%$ (skor). Kinerja dikatakan "baik" apabila lebih dari $80 \%$ dan diasumsikan bahwa $80 \%$ sama dengan 0,6. Sisanya adalah daerah "cukup", yaitu antara 0-0,6. Dari hasil data kuesioner diatas menunjukkan hasil rata-rata adalah 0,5 artinya kinerja Dinas Koperasi Usaha Mikro dan Tenaga Kerja Kabupaten Sampang dikatakan Cukup.

\section{Internal Bisnis Perspective (Perspektif proses bisnis internal)}

Untuk mengetahui bagaimana mengukur bisnis internal utamanya dalam mengukur peningkatan jaringan dalam unit kerja, rumus yang digunakan adalah:

$$
\text { NGR }=\frac{\sum \text { Unit Kerja }}{\text { Total Unit Kerja Secara Keseluruhan }} \times 100 \%
$$

Network Growth Ratio (NGR) akan melakukan pengukuran atas jaringan pada unit kerja dengan melakukan perbandingan peningkatan jaringan unit kerja terhadap total unit kerja pada periode tertentu.

$$
\mathrm{NGR}=\frac{8 \text { Unit Kerja }}{\mathrm{X}} 100 \%=80 \%
$$

10 Unit Kerja Keseluruhan

Dalam menentukan kriteria kinerja "kurang", "cukup", dan "baik" dengan membuat skala penilaian kinerja balanced scorecard dari hasil pemberian skor pada masing-masing hasil kuesioner yang diperoleh. Kinerja dikatakan "kurang" jika besar nilainya kurang dari $50 \%$ (skor). Kinerja dikatakan "baik" apabila lebih dari $80 \%$ dan diasumsikan bahwa $80 \%$ sama dengan 0,6. Sisanya adalah daerah "cukup", yaitu antara 0-0,6. Dari hasil data 


\section{REFORMASI}

ISSN 2088-7469 (Paper) ISSN 2407-6864 (Online)

Volume 8 Nomor 2 (2018)

perspektif bisnis internal diatas menunjukkan hasil NGR adalah $80 \%$ artinya kinerja Dinas Koperasi Usaha Mikro dan Tenaga Kerja Kabupaten Sampang dikatakan baik.

4. Learning and Growth Perspective (pembelajaran dan pertumbuhan)

a. Tingkat Kepuasan Karyawan

Dengan menggunakan survey, organisasi dapat jauh lebih mudah untuk mengukur sejauh mana karyawan merasa puas bekerja dan berkarya pada organisasi tersebut. Untuk menghitung hasil survey atas kepuasan kerja karyawan, digunakan rumus sebagai berikut:

$$
\begin{aligned}
& \text { Kepuasan Karyawan }=\frac{\sum \text { Total Nilai Rata-Rata Responden }}{\text { Total Pernyataan }} \times 100 \% \\
& \text { Kepuasan Karyawan }=\frac{0,5}{100 \%=5 \%}
\end{aligned}
$$

Dalam menentukan kriteria kinerja "kurang", "cukup", dan "baik" dengan membuat skala penilaian kinerja balanced scorecard dari hasil pemberian skor pada masingmasing hasil kuesioner yang diperoleh. Kinerja dikatakan "kurang" jika besar nilainya kurang dari 50\% (skor). Kinerja dikatakan "baik" apabila lebih dari $80 \%$ dan diasumsikan bahwa $80 \%$ sama dengan 0,6 . Sisanya adalah daerah "cukup", yaitu antara 0-0,6. Dari hasil data perspektif bisnis internal diatas menunjukkan hasil target kepuasan karyawan adalah 5\% artinya kinerja Dinas Koperasi Usaha Mikro dan Tenaga Kerja Kabupaten Sampang dikatakan kurang.

b. Tingkat Presentase Pelatihan Karyawan

Semakin besar jumlah karyawan yang akan diberikan pelatihan, akan meningkatkan jumlah karyawan yang memiliki keterampilan sesuai harapan organisasi. Untuk mengetahui tingkat persentase pelatihan karyawan, digunakan rumus sebagai berikut:

$$
\begin{aligned}
& \text { Karyawan yang diberikan pelatihan } \\
& \text { Persentase Karyawan Terampil }=\frac{\text { Total Jumlah Karyawan }}{\mathrm{X} 100 \%} \\
& 9 \\
& \text { Persentase Karyawan Terampil }=\longrightarrow \text { X } 100 \%=50 \% \\
& 18
\end{aligned}
$$




\section{REFORMASI}

ISSN 2088-7469 (Paper) ISSN 2407-6864 (Online)

Volume 8 Nomor 2 (2018)

\section{KESIMPULAN}

Berdasarkan hasil penelitian yang diperoleh dengan membandingkan teori yang ada maka dapat ditarik kesimpulan bahwa hasil Kinerja Pegawai secara Keseluruhan dapat dilihat pada hasil penilaian kinerja dari perspektif keuangan yang menunjukkan bahwa ROE mempunyai rata-rata cukup, sehingga diberi skor 0 . Karena rata-rata ROE sudah hampir mendekati standar yang telah ditetapkan. Sedangkan pada ROA menunjukkan ratarata kurang, sehingga diberi skro -1. Karena nilai ROA masih jauh dibawah standar yang ada. Untuk Operating Income diberi skor 0 karena mempunyai rata-rata cukup, dan untuk Efficiency Cost diberi skor 1 karena nilai sudah baik.

Dari hasil analisis data menunjukkan bahwa hasil rata-rata adalah 0,5 yang berarti kinerja Dinas Koperasi Usaha Mikro dan Tenaga Kerja Kabupaten Sampang dikatakan Cukup. Hasil tersebut merupakan hasil rata-rata dari beberapa aspek yang telah disebukan di atas, diantaranya data perspektif bisnis internal menunjukkan hasil NGR sebesar $80 \%$ artinya kinerja Dinas Koperasi Usaha Mikro dan Tenaga Kerja Kabupaten Sampang dikatakan baik. Data perspektif bisnis internal menunjukkan hasil target kepuasan karyawan sebesar 5\% artinya kinerja Dinas Koperasi Usaha Mikro dan Tenaga Kerja Kabupaten Sampang dikatakan kurang. Data perspektif bisnis internal menunjukkan hasil persentase pelatihan karyawan sebesar 50\% yang artinya kinerja Dinas Koperasi Usaha Mikro dan Tenaga Kerja Kabupaten Sampang dikatakan kurang. Data perspektif bisnis internal menunjukkan persentase pelatihan karyawan sebesar 50\% yang artinya kinerja Dinas Koperasi Usaha Mikro dan Tenaga Kerja Kabupaten Sampang dikatakan kurang.

\section{DAFTAR PUSTAKA}

Azizah, Rina. 2015. Pemberdayaan Masyarakat Dalam Mengurangi Angka Pengangguran di Kabupaten Sampang. Tesis tahun 2015. Malang. Universitas Bawijaya.

Badan Pusat Statistik (BPS) Kabupaten Sampang. 2013. Jumlah Penduduk di Kabupaten Sampang. Pemkab Sampang.

Dwiyanto, Agus. 2012. Manajemen Pelayanan Publik. Edisi Kedua. Yogyakarta. Gadjah Mada University Press.

Hariadi, Sandytya. 2009. Strategi Dinas Sosial Tenaga Kerja dan Transmigrasi Dalam Mengurangi Angka Pengangguran di Kota Surakarta. Universitas Negeri Sebelas Maret. Surakarta. Skripsi Tahun 2009.

Mahmudi. 2010. Manajemen Kinerja Sektor Publik. Edisi Kedua. Yogyakarta. UPP STIM YKPN.

Mahsun, Mohamad. 2006. Pengukuran Kinerja Sektor Publik. Edisi Pertama. Yogyakarta. BPFE-Yogyakarta.

Team Pembina Mata Kuliah Manajemen Strategi. Manajemen Strategi. Surabaya. Program Magister Manajemen. Program Pascasarjana Universitas Wijaya Putra. 